\title{
Lysine efficiency in piglets fed diets with a phytogenic feed additive and conclusion of lysine requirement data
}

\author{
A. Muhl and F. Liebert ${ }^{1}$ \\ Department of Animal Sciences, Division Animal Nutrition Physiology, \\ Georg-August-University \\ Kellnerweg 6, D-37077 Goettingen, Germany
}

(Received 10 February 2009; revised version 21 May 2009; accepted 29 January 2010)

\begin{abstract}
Two experiments were conducted to examine effects of a commercial phytogenic feed additive (PFA), containing inulin, an essential oil mix (carvacrol, thymol), and chest nut meal (polyphenols) on nutrient digestibility, protein utilization, and lysine efficiency in piglets. Each experiment utilized sixteen piglets (male castrated, $8 \mathrm{wk}$ ) and four experimental groups. Experiment 1 studied graded levels of the PFA $(0,0.05,0.1,0.15 \%)$ in lysine limited diets (wheat, barley, soyabean meal, fish meal). Experiment 2 examined $0.1 \%$ of the PFA and two dietary levels of lysine. The results indicated that apparent nutrient digestibility, protein utilization, and lysine efficiency were not significantly affected by the PFA $(P>0.05)$. Observed daily lysine requirements $(7.3,9.9$ and $13.1 \mathrm{~g}$ for $76,100,124 \mathrm{~g}$ daily protein deposition) in growing barrows (20-30 $\mathrm{kg}$ body weight) were in line with recommendations and contribute to the limited database for modelling of lysine requirements in piglets.
\end{abstract}

KEY WORDS: piglets, protein utilization, feed additives, lysine

\section{INTRODUCTION}

Mixtures of herbs, spices and essential oils are currently. applied to achieve feed intake, growth and health promoting effects in several animal species. However, mode of action and potential of phytogenic feed additives (PFA) in vivo

\footnotetext{
' Corresponding author: e-mail: flieber@gwdg.de
} 
is mostly unknown. Currently, contradictory observations do not withstand an objective and critical judgement. Additionally, the diversity of PFA mixtures allows no general conclusion (Jeroch et al., 2008). Earlier studies with a commercial PFA examined zootechnical data, parameters of gut microflora, digestive enzyme activity and unspecific immune response in weaned piglets (Muhl and Liebert, $2007 \mathrm{a}, \mathrm{b}$ ). The current study investigated parameters of digestibility, protein utilization and dietary lysine efficiency. A validated procedure (Liebert, 2008; Liebert and Wecke, 2008; Wecke and Liebert, 2009) for modelling of protein utilization depending on observed dietary amino acid efficiency was applied for conclusion of lysine requirement data for piglets.

\section{MATERIAL AND METHODS}

N-balance experiments were conducted making use of a commercial PFA containing the fructopolysaccharide inulin $(53 \%)$ from Jerusalem artichoke, an essential oil mix from oregano oil $(8 \%)$, tannins from chest nut meal $(3 \%)$ and cellulose powder $(36 \%)$, respectively. An external gas chromatographic analysis of the PFA yielded $6.0 \%$ carvacrol and $0.14 \%$ thymol.

\section{Animals and diets}

Each of the experiments was carried out on sixteen male castrated eight week old piglets [Piètrain $\times($ Large White $\times$ German Landrace $)$ ]. Piglet mash diets were based on the main ingredients: wheat, soyabean meal, barley and fish meal, respectively.

Experiment 1 examined three graded levels of the PFA under study (Table 1) for investigation of effects of the additive on dietary lysine efficiency. To adjust lysine in the first limiting position, the dietary lysine supply was approximately $80 \%$ of the NRC (1998) recommendation (Table 2). Experiment 2 utilized only one level of PFA addition, but supplemented crystalline lysine (Table 1, diets C, D) to approve the limiting position of lysine and to examine the PFA effect at optimal lysine supply.

Balance studies were conducted with individual metabolism cages making use of an adaptation period of five days and two consecutive collecting periods (five days each). For standardization of feed intake during the collecting periods, piglets were restrictive fed twice a day.

\section{Sampling}

Faeces were quantitatively collected twice a day during morning and afternoon 
feeding and stored at $-18^{\circ} \mathrm{C}$ for further analyses. In order to minimize ammonia losses, the urine was acidified ( $\mathrm{pH}$ below 2) with $60 \mathrm{~g}$ of sulphuric acid $(30 \%)$. Individual aliquots of the daily urine sampling were stored at $4^{\circ} \mathrm{C}$, carefully mixed and further analysed.

Table 1. Composition of the basal diet in experiment 1 and $2, \mathrm{~g} / \mathrm{kg}$

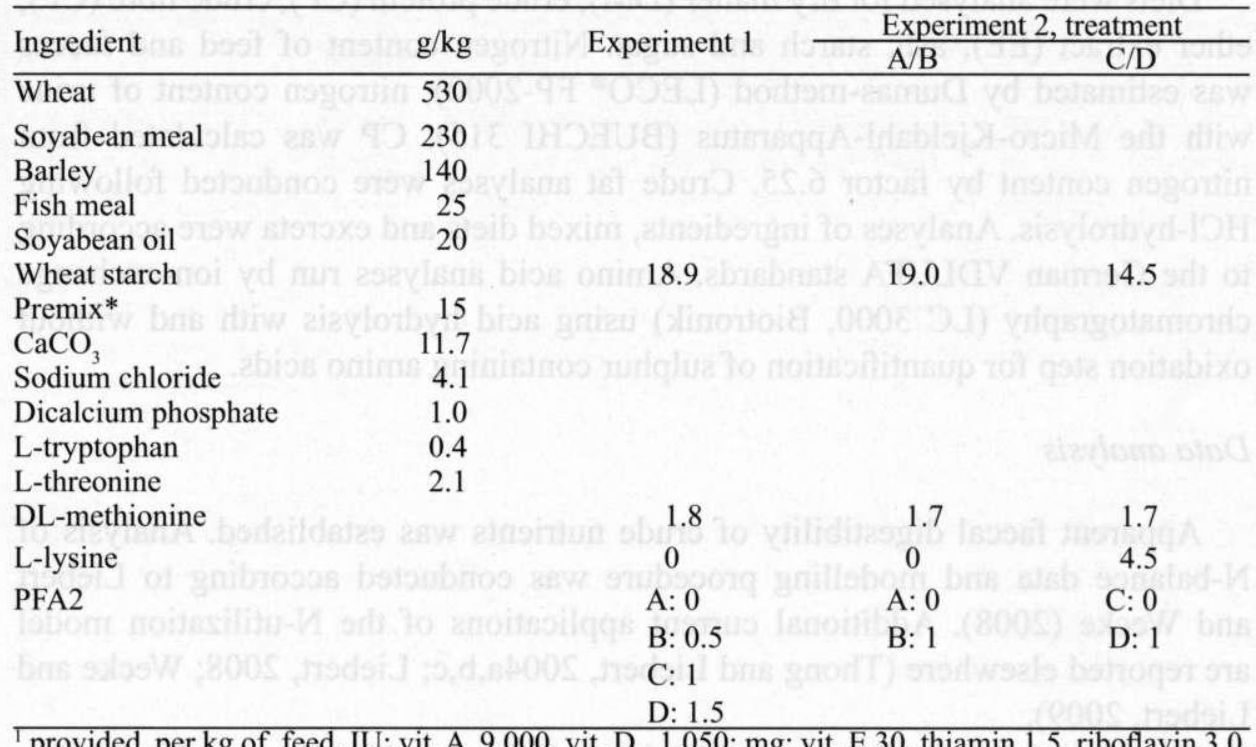

provided per kg of feed, IU: vit. A 9.000, vit. $\mathrm{D}_{3} 1.050$; $\mathrm{mg}$ : vit. E 30, thiamin 1.5, riboflavin 3.0, vit. $\mathrm{B}_{6} 3$, vit. $\mathrm{K}_{3} 3.0$, nicotinic acid 18.8, Ca-pantothenate 11.3 , folic acid $0.6, \mathrm{Fe} 150, \mathrm{Cu} 30, \mathrm{Mn}$ 37.5, Zn 150, I 0.23, Se 0.23, Co 0.75; g: Ca 1.8, P 2.1, Na 0.08, Mg 0.1; $\mu$ g: biotin 225, vit. B 30; ${ }^{2}$ PFA composition, per kg; g: inulin 530, essential oil mix (mainly thymol and carvacrol) 80 , tannins 30 , cellulose powder 360

Table 2. Nutrient composition of the basal diets, $\mathrm{g} / \mathrm{kg}$ DM

\begin{tabular}{lcc}
\hline Ingredient & \multicolumn{2}{c}{ Experiment } \\
\cline { 2 - 3 } Crude protein & 1 & 2 \\
Ether extract & 225.8 & 229.0 \\
Crude fibre & 50.1 & 51.9 \\
Crude ash & 38.3 & 36.5 \\
N-free extractives & 65.4 & 66.1 \\
Lysine & 620.4 & 616.5 \\
& 11.5 & 11.5 (Diets A + B) \\
Threonine & & 15.4 (Diets C + D) \\
Methionine + cystine & 10.0 & 10.0 \\
Metabolizable energy & 9.3 & 9.3 \\
Calculated according to Kirchgessner and & $15.9 \mathrm{MJ}$ & $16.0 \mathrm{MJ}$ \\
\hline
\end{tabular}

calculated according to Kirchgessner and Roth (1983) 
All experimental protocols were approved by the Animal Welfare Committee of the Agricultural Faculty of Goettingen University.

\section{Chemical analysis}

Diets were analysed for dry matter (DM), crude protein (CP), crude fibre (CF), ether extract (EE), ash, starch and sugar. Nitrogen content of feed and faeces was estimated by Dumas-method (LECO ${ }^{62}$ FP-2000), nitrogen content of urine with the Micro-Kjeldahl-Apparatus (BUECHI 315). CP was calculated from nitrogen content by factor 6.25. Crude fat analyses were conducted following $\mathrm{HCl}$-hydrolysis. Analyses of ingredients, mixed diets and excreta were according to the German VDLUFA standards. Amino acid analyses run by ion-exchange chromatography (LC 3000, Biotronik) using acid hydrolysis with and without oxidation step for quantification of sulphur containing amino acids.

\section{Data analysis}

Apparent faecal digestibility of crude nutrients was established. Analysis of $\mathrm{N}$-balance data and modelling procedure was conducted according to Liebert and Wecke (2008). Additional current applications of the N-utilization model are reported elsewhere (Thong and Liebert, 2004a,b,c; Liebert, 2008; Wecke and Liebert, 2009).

The basic function of the model is given in equation (1):

$$
\mathrm{NR}=\mathrm{NR}_{\max } \mathrm{T}\left(1-\mathrm{e}^{-\mathrm{b} \cdot \mathrm{N} I}\right)
$$

where: NR - daily N-retention $\left(\mathrm{mg} / \mathrm{BW}_{\mathrm{kg}}{ }^{0.67}\right)=$ Daily N-deposition + NMR; $\mathrm{NMR}$ - daily $\mathrm{N}$-maintenance requirement $\left(\mathrm{mg} / \mathrm{BW}_{\mathrm{kg}}{ }^{0.67}\right) ; \mathrm{NR}_{\max } \mathrm{T}$ - theoretical maximum for daily $\mathrm{N}$-retention $\left(\mathrm{mg} / \mathrm{BW}_{\mathrm{kg}}{ }^{0.67}\right)$; $\mathrm{b}$ - model parameter for the slope of the exponential function, depending on the dietary protein quality; NI - daily $\mathrm{N}$-intake $\left(\mathrm{mg} / \mathrm{BW}_{\mathrm{kg}}{ }^{0.67}\right)$; $\mathrm{c}$ - basic number of natural logarithm (ln).

Model parameters $\mathrm{NMR}$ and $\mathrm{NR}_{\max } \mathrm{T}$ were taken from earlier studies with similar genotype barrows (Wecke and Liebert, 2009). Assessment of dietary protein quality (b) utilized equation (2):

$$
\mathrm{b}=\ln \left[\mathrm{NR}_{\max } \mathrm{T}-\ln \left(\mathrm{NR}_{\max } \mathrm{T}-\mathrm{NR}\right)\right]: \mathrm{NI}
$$

Net protein utilization (NPU) data were standardized for equal daily $\mathrm{N}$-intake ( $3650 \mathrm{mg} / \mathrm{BW}_{\mathrm{kg}}{ }^{0.67}$ ) according to Thong and Liebert (2004a). The applied procedure for modelling lysine requirements was according to earlier reports (Thong and 
Liebert, 2004b,c).

Equation (3) summarises the derived requirement dependent on NR and observed dietary amino acid efficiency $\left(b c^{-1}\right)$ :

$$
\mathrm{LAAI}=\left[\ln \mathrm{NR}_{\max } \mathrm{T}-\ln \left(\mathrm{NR}_{\max } \mathrm{T}-\mathrm{NR}\right)\right]: 16 \mathrm{bc}^{-1}
$$

where: LAAI - required daily intake of the limiting amino acid for a given NR, $\mathrm{mg} / \mathrm{BW}_{\mathrm{kg}}{ }^{0.67} ; \mathrm{bc}^{-1}$ - model parameter for the dietary amino acid efficiency.

\section{Statistical analysis}

Statistical data analysis utilized ANOVA ( $\mathrm{P}<0.05$ or higher) within the programme SPSS 12.0 for Windows. Data were subjected to a verification of variance homogeneity according to Levene test, following LSD in case of homogeneity of variance. Following in-homogeneity of variance, the GamesHowell post-hoc test was applied.

\section{RESULTS}

Apparent nutrient digestibility. Digestibility of crude nutrients (Table 3) did not significantly respond to the added PFA. The dietary lysine supply was not a significant factor for the observed results of the digestibility study.

Table 3. Apparent digestibility of crude nutrients, $\%$

\begin{tabular}{cccccc}
\hline \multirow{2}{*}{$\begin{array}{c}\text { Experiment } \\
\text { Treatment }\end{array}$} & $\begin{array}{c}\text { Crude protein } \\
\%\end{array}$ & $\begin{array}{c}\text { Crude fibre } \\
\%\end{array}$ & $\begin{array}{c}\text { Ether extract } \\
\%\end{array}$ & $\begin{array}{c}\text { N-free extractives } \\
\%\end{array}$ \\
\hline \multirow{4}{*}{1} & A & $89.5^{\mathrm{a}} \pm 2.31$ & $46.7^{\mathrm{a}} \pm 6.55$ & $74.4^{\mathrm{a}} \pm 4.31$ & $93.7^{\mathrm{a}} \pm 0.67$ \\
& B & $89.1^{\mathrm{a}} \pm 1.98$ & $48.2^{\mathrm{a}} \pm 4.43$ & $74.8^{\mathrm{a}} \pm 5.17$ & $93.7^{\mathrm{a}} \pm 0.50$ \\
& C & $89.8^{\mathrm{a}} \pm 1.02$ & $49.4^{\mathrm{a}} \pm 4.43$ & $76.0^{\mathrm{a}} \pm 2.56$ & $93.6^{\mathrm{a}} \pm 0.58$ \\
& D & $89.8^{\mathrm{a}} \pm 1.12$ & $49.1^{\mathrm{a}} \pm 5.13$ & $76.0^{\mathrm{a}} \pm 3.12$ & $93.9^{\mathrm{a}} \pm 0.33$ \\
& & & & \\
& A & $90.6^{\mathrm{a}} \pm 0.90$ & $50.7^{\mathrm{a}} \pm 6.29$ & $77.2^{\mathrm{a}} \pm 1.23$ & $93.7^{\mathrm{a}} \pm 0.57$ \\
& B & $90.8^{\mathrm{a}} \pm 2.13$ & $49.7^{\mathrm{a}} \pm 7.36$ & $77.8^{\mathrm{a}} \pm 2.22$ & $93.9^{\mathrm{a}} \pm 0.49$ \\
& C & $89.8^{\mathrm{a}} \pm 2.10$ & $49.4^{\mathrm{a}} \pm 6.84$ & $79.1^{\mathrm{a}} \pm 1.91$ & $93.9^{\mathrm{a}} \pm 0.56$ \\
& D & $89.6^{\mathrm{a}} \pm 0.61$ & $49.5^{\mathrm{a}} \pm 3.38$ & $78.3^{\mathrm{a}} \pm 2.10$ & $93.8^{\mathrm{a}} \pm 0.45$ \\
\hline
\end{tabular}

means with different superscript letters are significantly different $(\mathrm{P}<0.05)$

Nitrogen balance studies. Daily $\mathrm{N}$-balance, N-utilization and dietary lysine efficiency were not significantly affected by the added PFA (Table 4). Supplementation of crystalline lysine in diets $\mathrm{C}$ and $\mathrm{D}$ (Experiment 2) improved $\mathrm{N}$-utilization significantly. Consequently, lysine was confirmed to be in first limiting position in all of the diets not supplemented with crystalline lysine. 
Table 4. Results of the $\mathrm{N}$-balance study $(\mathrm{n}=8$; mean BW: experiment $\mathrm{I}=23.2 \mathrm{~kg}$, experiment II $=$ $25.21 \mathrm{~kg}$ )

\begin{tabular}{|c|c|c|c|c|c|c|c|}
\hline Experiment & $\begin{array}{l}\text { Treat- } \\
\text { ment }\end{array}$ & $\begin{array}{c}\mathrm{N} \text {-intake } \\
\mathrm{mg}_{\mathrm{B} W_{\mathrm{kg}}}^{0.67 / \mathrm{d}}\end{array}$ & $\begin{array}{c}\text { N-balance } \\
\mathrm{g} / \mathrm{d}\end{array}$ & $\begin{array}{c}\mathrm{N} \text {-digestibility } \\
\%\end{array}$ & $\begin{array}{c}\text { N-utilization* } \\
\%\end{array}$ & $\begin{array}{c}\mathrm{NPU}^{* *} \\
\%\end{array}$ & $\begin{array}{c}\text { Lysine } \\
\text { efficiency } \\
\mathrm{bc}^{-1}\end{array}$ \\
\hline \multirow{4}{*}{1} & $\mathrm{~A}$ & $3567^{a}$ & $15.25^{\mathrm{a}}$ & $89.54^{a}$ & $50.33^{\mathrm{a}}$ & $61.80^{a}$ & $37^{a}$ \\
\hline & B & $3570^{\mathrm{a}}$ & $14.62^{\mathrm{a}}$ & $89.10^{\mathrm{a}}$ & $49.66^{\mathrm{a}}$ & $69.90^{\mathrm{a}}$ & $35^{a}$ \\
\hline & $\mathrm{C}$ & $3710^{a}$ & $15.18^{\mathrm{a}}$ & $89.80^{\mathrm{a}}$ & $51.70^{\mathrm{a}}$ & $62.00^{\mathrm{a}}$ & $37^{\mathrm{a}}$ \\
\hline & D & $3693^{a}$ & $15.41^{\mathrm{a}}$ & $89.76^{\mathrm{a}}$ & $50.99^{\mathrm{a}}$ & $62.54^{\prime \prime}$ & $37^{a}$ \\
\hline \multirow{4}{*}{2} & A & $3598^{a}$ & $15.67^{\mathrm{a}}$ & $90.56^{3}$ & $51.95^{\mathrm{a}}$ & $63.14^{\mathrm{a}}$ & $38^{\mathrm{a}}$ \\
\hline & B & $3405^{a}$ & $14.63^{a}$ & $90.75^{\mathrm{a}}$ & $51.81^{\circ}$ & $59.89^{\mathrm{a}}$ & $35^{a}$ \\
\hline & $\mathrm{C}$ & $3459^{a}$ & $19.73^{b}$ & $89.84^{a}$ & $63.34^{\mathrm{b}}$ & $73.93^{b}$ & $37^{a}$ \\
\hline & D & $3431^{a}$ & $19.67^{\mathrm{b}}$ & $89.55^{a}$ & $63.47^{\mathrm{b}}$ & $73.80^{\mathrm{b}}$ & $37^{\mathrm{a}}$ \\
\hline
\end{tabular}

means with different superscript letters are significantly different $(\overline{\mathrm{P}}<0.05) ;{ }^{*} \mathrm{~N}$-balance: $\mathrm{N}$-intake, $\%$; ** net protein utilization standardized for $3650 \mathrm{mg} / \mathrm{BW}_{\mathrm{kg}}^{0.67} / \mathrm{d} \mathrm{N}$-intake; N-retention: $\mathrm{N}$-intake

Modelling of lysine requirement data. Conclusion of lysine requirement data (Table 5) was not in first focus of the conducted experiments. However, approved limiting position of lysine provided an additional database to improve information about quantitative lysine requirements for piglets. Requirements were derived for 40,50 and $60 \%$ of the growth potential $\left(\mathrm{NR}_{\max } \mathrm{T}\right)$, according to graded daily protein deposition $(76,100$ and $124 \mathrm{~g}$ daily protein gain at 24.2 $\mathrm{kg}$ average BW). Assuming 17.0\% crude protein in daily gain (GRRS 2006. 2008 ), these protein deposition data were equal with 447,588 and $729 \mathrm{~g}$ daily gain of $\mathrm{BW}$. Additionally, according to the applied modelling procedure the requirements were also derived for graded dietary efficiency of lysine (Table 6).

Table 5. Model calculation of lysine requirement for piglets (20 to $30 \mathrm{~kg}$ ) depending on daily CP-deposition, observed efficiency of dietary lysine utilization and predicted feed intakc

\begin{tabular}{lccc}
\hline CP-dcposition, g/d & $76^{1}$ & $100^{2}$ & $124^{3}$ \\
\hline Lys-efficiency, bc ${ }^{-1}$ & & 37 & \\
Lys-requirement, $\mathrm{mg}_{\mathrm{g} / \mathrm{BW}_{\mathrm{kg}}{ }^{0.67} / \mathrm{d}}$ & 863 & 1171 & 1548 \\
$\qquad$ & 7.3 & 9.9 & 13.1
\end{tabular}

Optimal dietary lysine concentration (\%) depending on feed intake predicted feed intake, $\mathrm{g} / \mathrm{d}$

\begin{tabular}{cccc}
900 & 0.81 & 1.10 & 1.46 \\
1000 & 0.73 & 0.99 & 1.31 \\
1100 & 0.66 & 0.90 & 1.19 \\
\hline $40 \%$ of NR $\max ^{\mathrm{T}} \mathrm{T}$ at $\mathrm{BW}=24.2 \mathrm{~kg} ;{ }^{2} 50 \%$ of $\mathrm{NR}_{\max } \mathrm{T}$ at $\mathrm{BW}=24: 2 \mathrm{~kg} ;{ }^{3} 60 \%$ of $\mathrm{NR}_{\max } \mathrm{T}^{2}$ at \\
$\mathrm{BW}=24.2 \mathrm{~kg} ;{ }^{4} \mathrm{BW}=24.2 \mathrm{~kg}$
\end{tabular}

Based on predictions for the daily feed intake of piglets which were in line with feed intake pattern observed in the current experiments, recommendations for the optimal dietary lysine supply (as \% of diet) were concluded. 
Table 6. Model calculation of lysine requirement for piglets (20 to $30 \mathrm{~kg}$ ) with varying dietary efficiency of lysine utilization

\begin{tabular}{lccc}
\hline CP-deposition, g/d & & $100^{1}$ & \\
\hline Lys-efficiency, bc ${ }^{-1}$ & $33^{2}$ & $37^{3}$ & $41^{4}$ \\
Lys-requirement, $\mathrm{mg} / \mathrm{BW}_{\mathrm{kg}}{ }_{\mathrm{g} / \mathrm{d}^{5}}$ & 1313 & 1171 & 1057 \\
& 11.1 & 9.9 & 8.9
\end{tabular}

Optimal dietary lysine concentration (\%) depending on feed intake predicted feed intake, $\mathrm{g} / \mathrm{d}$

$\begin{array}{rrrr}900 & 1.23 & 1.10 & 0.99 \\ 1000 & 1.11 & 0.99 & 0.89 \\ 1100 & 1.01 & 0.90 & 0.81\end{array}$

$50 \%$ of $\mathrm{NR}_{\mathrm{max}} \mathrm{T}$ at $\mathrm{BW}=24.2 \mathrm{~kg} ;{ }^{2} 10 \%$ below the observed efficiency of dietary lysine utilization; ${ }^{3}$ observed lysine elficiency; ${ }^{4}$ 10\% above the observed efficiency of dietary lysine utilization; ${ }^{5} \mathrm{BW}=24.2 \mathrm{~kg}$

\section{DISCUSSION}

Commercial phytogenic feed additives are varying in supply of individual bioactive substances. Consequently, several studies observed improved nutrient digestibility by supplementation of essential oils, but other reports failed to yield significant effects (Möller, 2001). Wald (2002) summarized that positive effects of essential oils are only caused by their antimicrobial action which could contribute to improve nutrient and energy utilization in the host animal. However, according to Wald (2002) our previous studies (Muhl and Liebert, 2007a,b) did not yield significant growth effects. Enhanced activity of digestive enzymes (Platel et al., 2002) was not supported by results of Muhl and Liebert (2007b).

According to Möller (2001), presented N-balance data failed to show significant effects of the PFA under study. According to Branner et al. (2004), no effect on total $\mathrm{N}$-excretion, $\mathrm{N}$-retention and $\mathrm{N}$-excretion via urine was attributed to supplementation of inulin. However, due to supplied native prebiotic compounds in pig feeds effects of low quantity of added prebiotics is questionable. Furthermore, masking or dilution by dietary oligosaccharides from cereals is also discussed (Gabert et al., 1995). However, experimental data for inulin effects on availability and retention of nutrients are scarce (Verdonk et al., 2005). In the current study, the very low supply of added inulin from the PFA under study was not sufficient to induce any significant effect. Mosenthin and Zimmermann (2000) concluded that healthy and well-kept animals not crucial exposed to pathogenic bacteria and stress factors will scarcely respond to this type of feed additives.

The insignificant effects of the PFA on observed dietary lysine efficiency provided data for modelling of lysine requirements. In 'growing barrows $(20-30 \mathrm{~kg}$ BW) 7.3, 9.9 and $13.1 \mathrm{~g}$ lysine per day were required for 76,100 and $124 \mathrm{~g}$ daily 
protein deposition. These data were in line with NRC (1998) recommendations (10-20 kg BW: $11.5 \mathrm{~g} / \mathrm{d} ; 20-50 \mathrm{~kg} \mathrm{BW}: 17.5 \mathrm{~g} / \mathrm{d})$. In terms of total lysine, earlier German recommendations vary between 7.2 and $12.3 \mathrm{~g}$ lysine per day (20-25 $\mathrm{kg} \mathrm{BW}, 300-600 \mathrm{~g}$ daily gain). Actual German recommendations (GRRS, 2006, 2008 ) advise 10.1 and $12.1 \mathrm{~g}$ lysine per day for 500 and $600 \mathrm{~g}$ daily gain (25 kg $\mathrm{BW}$ ) in terms of standardized praecaecal digestible lysine. Assuming $85 \%$ as an average of ileal lysine digestibility, these recommendations are in the scope of presented requirement data for $100 \mathrm{~g}$ daily protein deposition. Our reported lysine requirement data for piglets are also in line with several other studies (Gatel et al., 1992; Whittemore et al., 2003; Wecke and Liebert, 2009). For feed formulation, Bertolo et al. (2005) recommended $0.91 \%$ ileal digestible lysine $(24.1 \mathrm{~kg} \mathrm{BW}$; $982 \mathrm{~g}$ daily feed intake), which are in line with our data $(85 \%$ predicted ileal lysine digestibility) and several other studies (Martinez and Knabe, 1990; Coma et al., 1995). In contrast, $\mathrm{Fu}$ et al. (2004) recommended $1.32 \%$ true digestible lysine for late nursery pig diets $(29 \mathrm{~kg} \mathrm{BW})$. Generally, the applied procedure makes use of benchmarks for modelling amino acid requirements which can be adapted to different needs, like genotype, individual BW and the aimed daily protein deposition as important factors of influence (Martinez and Knabe, 1990; Cromwell et al., 1993; Thong and Liebert, 2004a,b,c).

\section{CONCLUSIONS}

According to our previous studies, no significant response was observed due to application of a commercial phytogenic feed additive (PFA) in piglet diets, but more investigations are needed to clarify mode of action and efficacy of PFA mixtures under several environmental circumstances. The applied modelling procedure was confirmed as a reliable tool to improve database for lysine recommendations in piglets.

\section{REFERENCES}

Bertolo R.F., Moehn S., Pencharz P.B., Ball R.O., 2005. Estimate of the variability of the lysine requirement of growing pigs using the indicator amino acid oxidation method. J. Anim. Sci. 83, 2535-2542

Branner G.R., Böhmer B.M., Erhardt W., Henke J., Roth-Maier D.A., 2004. Investigations on the precaecal and faccal digestibility of lactulose and inulin and their influence on nutrient digestibility and microbial characteristics. Arch. Anim. Nutr. 58, 353-366

Coma J., Zimmermann D.R., Carrion D., 1995. Interactive effects of feed intake and stage of growth on the lysine requirement of pigs. J. Anim. Sci. 73, 3369-3375 
Cromwell G.L., Cline T.R., Crenshaw J.D., Ewan R.C., Hamilton C.R., Lewis A.J., Mahan D.C., Miller E.R., Pettigrew J.E., Tribble L.F., Veum T.L., 1993. The dietary protein and (or) lysine requirements of barrows and gilts. J. Anim. Sci. 71, 1510-1519

Fu S.X., Gaines M., Ratliff B.W., Srichana P., Allee G.L., Usry J.L., 2004. Evaluation of the true ilcal digestible (TID) lysine requirement for 11 to $29 \mathrm{~kg}$ pigs. J. Anim. Sci. 82, Suppl. 1, 294 (Abstr.)

Gabert V.M., Sauer W.C., Mosenthin R., Schmitz M., Ahrens F., 1995. The effect of oligosaccharides and lactitol on the ileal digestibilities of amino acids, monosaccharides and bacterial populations and metabolites in the small intestine of weanling pigs. Can. J. Anim. Sci. 75, 99-107

Gatel F., Buron G., Fékéte J., 1992. Total amino acid requirements of weaned piglets 8 to $25 \mathrm{~kg}$ live weight given diets based on wheat soy-bean meal fortified with free amino acids. Anim. Prod. $54,281-287$

German Recommendations for Requirement Standards (GRRS), 2006, 2008. Gesellschaft für Ernährungsphysiologie (GfE), Ausschuss für Bedarfsnormen: Empfehlungen zur Energie- und Nährstoffversorgung von Schweinen. DLG-Verlag, Frankfurt am Main

Jeroch H., Kozlowski K., Lipinski K., Jeroch J., Zdunczyk Z., Jankowski J., 2008. Zur Wirksamkeit von Phytobiotika bei wachsenden monogastrischen Nutztieren am Beispiel von PapaveraceaePräparaten. Proceedings of 10. Tagung Schweinc- und Geflügelernährung. Halle (Germany), pp. 47-55

Kirchgessner M., Roth F.X., 1983. Equation for prediction of the energy value in mixed feeds for pigs. J. Anim. Physiol. Anim. Nutr. 50, 270-275

Liebert F., 2008 Modelling of protein metabolism yiclds amino acid requirements dependent on dietary amino acid efficiency, growth response, genotype and age of growing chicken. Avian Biol. Rev. I, 101-110

Liebert F., Wecke C., 2008. Models for further developing the evaluation of protein and amino acids as well as for predicting performance from energy and amino acids intake. In: Recommendations for the Supply of Energy and Nutrients to Pigs. Committee for Requirement Standards of the Society of Nutrition Physiology. DLG-Verlags-GmbH, Frankfurt am Main, pp. 219-230

Martinez G.M., Knabe D.A., 1990. Digestible lysine requirement of starter and grower pigs. J. Anim. Sci. 68, 2748-2755

Möller T., 2001. Untersuchungen zum Einfluß eines Oreganoöl-Zusalzes zum Futter auf die Rohnährstoffverdaulichkeit; N-Bilanz sowie auf Parameter des mikrobiellen Stoffwechsels im Verdauungstrakt von Absetzferkeln. Doctoral Thesis. Tierärztliche Hochschule, Hannover (Germany)

Mosenthin R, Zimmermann B., 2000. Probiotics and prebiotics in pig nutrition - alternatives for antibiotics? In: Selected Topics in Animal Nutrition,. Biochemistry and Physiology. In: W. J. He. Sauer (Editor). University of Alberta. Edmonton, Alberta (Canada), pp. 29-50

Muhl A., Liebert F., 2007a. Growth and parameters of microflora in intestinal and fecal samples of piglets due to application of a phytogenic feed additive. J. Anim. Physiol. Anim. Nutr. 91, $411-418$

Muhl A., Liebert F., 2007b. No impact of a phytogenic feed additive on digestion and unspecific immune reaction in piglets. J. Anim. Physiol. Anim. Nutr. 91, 426-431

NRC, 1998. Nutrient Requirements of Swine. National Research Council. 10 $0^{\text {th }}$ revised Edition. Washington, DC

Platel K., Rao A., Saraswathi G., Srinivasan K., 2002. Digestive stimulant action of three Indian spice mixes in experimental rats. Nahrung 46, 394-398 
Thong H.T., Liebert F., 2004a. Potential for protein deposition and threonine requirement of modern genotype barrows fed graded levels of protein with threonine as the limiting amino acid. J. Anim. Physiol. Anim. Nutr. 88, 196-203

Thong H.T., Liebert F., 2004b. Amino acid requirement of growing pigs depending on amino acid efficiency and level of protein deposition. $1^{\text {st }}$ Communication: lysine. Arch. Anim. Nutr. 58, 69-88

Thong H.T., Liebert F., 2004c. Amino acid requirement of growing pigs depending on efficiency of amino acid utilisation and level of protein deposition. 2. Threonine. Arch. Anim. Nutr. 58, 157-168

Verdonk J.M.A.J., Shim S.B., van Leeuwen P., Verstegen M.W.A., 2005. Application of inulin-type fructans in animal and pet food. Brit. J. Nutr. 93, Suppl. 1, S125-S138

Wald C., 2002. Untersuchungen zur Wirksamkeit verschiedener ätherischer Öle im Futter von Aufzuchtferkeln und Broilern. Doctoral Thesis, Landwirtschaftliche Fakultät Halle-Wittenberg

Wecke C., Liebert F., 2009. Lysine requirement studies in modern genotype barrows dependent on age, protein deposition and dietary lysine efficiency. J. Anim. Physiol. Anim. Nutr. 93, 295-304

Whittemore C.T., Hazzledine M.J., Close W.H., 2003. Nutrient Requirement Standards for Pigs. British Society of Animal Science. Penicuik (UK) 